\title{
INFRARED THERMOGRAPHY IN ENERGY AUDIT OF ELECTRICAL INSTALLATIONS
}

\author{
Hrvoje Glavaš, Lajos Józsa, Tomislav Barić
}

Subject review

Energy Audit of Electrical Installations is an integral part of the overall energy audit of complex technical systems, and infrared thermography is one of the non-destructive testing (NDT) methods for that type of analysis of power distribution subsystems. During the energy audit of the power subsystem by means of a thermal camera, it is necessary to carry out some additional measurements of electrical quantities which are often not performed easily. The paper provides an overview of the standards in the field of thermography and safety criteria of electrical installations based on a thermal image and measured electrical parameters. As a practical example, an analysis of an electric power distribution subsystem of large complex industrial consumers is presented.The procedure of the audit and decision making for future maintenance is described in detail. Recommendations of corrective actions in the maintenance procedure based on the absolute temperature criterion and the delta-T criterion under consideration of the measured load are given as well.

Keywords: electrical power installations; fault rating; thermography

Infracrvena termografija u energetskom pregledu električnih instalacija

Pregledni članak

Energetski pregled elektroenergetskih sustava sastavni je dio energetskog pregleda složenih tehničkih sustava, a infracrvena termografija jedna je od nezaobilaznih nedestruktivnih metoda ovakve vrste analize elektroenergetskih podsustava. Prilikom energetskog pregleda elektroenergetskog sustava termokamerom potrebno je provesti dodatna mjerenja električnih veličina što se često ne može izvesti na jednostavan način. Rad daje pregled standarda na području termovizije i kriterija ispravnosti elektroenergetskih instalacija na osnovu termograma uzimajući u obzir izmjerene električne veličine. Na praktičnom primjeru velikog složenog industrijskog potrošača prikazan je detaljan postupak analize i donošenja suda o ispravnosti instalacija kao i preporuka korektivnih radnji u postupku održavanja.

Ključne riječi: elektroenergetske instalacije; ocjena ispravnosti; termografija

\section{Introduction}

Infrared thermography is a contactless method for determining the temperature distribution on the surface of the observed object by measuring the intensity of radiation in the infrared region of the electromagnetic spectrum. Thermography is often used as a maintenance tool. In the field of electric power engineering, thermography is an unavoidable test method closely associated with the measurement of electrical quantities. According to international standards, thermography is classified as one of the non-destructive testing methods (NDT). Standards in the field of thermal imaging are not unique, representing several different norms that are mainly related to certain technical fields. Criteria for validity and safety of electrical installations based on information from the thermogram are reduced to the analysis of absolute and relative temperature of the observed elements of the system, compared to similar components under similar load. The interpretation of thermograms depends primarily on the knowledge and experience of the user. As an example for this paper, an energy audit of a large complex industrial transformer substation (TS) of $10 / 0,4 \mathrm{kV}$ and associated distribution were carried out. Fig. 1 and Fig. 2 show the objects analysed.

The analysed system is essentially an industrial plant that consists of administrative buildings and production facilities. Office buildings are classified as non-residential buildings with complex technical systems. Energy requirements are settled by natural gas and electricity. Built in 1950, the plant consists of the administration building area of $487 \mathrm{~m}^{2}$ and the working area of $3414 \mathrm{~m}^{2}$. The annual natural gas and electricity consumption is $162269 \mathrm{~kW} \cdot \mathrm{h}$ and $167390 \mathrm{~kW} \cdot \mathrm{h}$, respectively. Natural gas is used for space heating, whereas electricity is used to power the machines. According to the above, it is evident that the continuous supply of electricity is essential to the business processes that take place in the space of a complex system. Fig. 1 and Fig. 2 show the main $10 / 0,4 \mathrm{kV}$ power supply transformer and the main board of the electricity distribution subsystem, respectively.

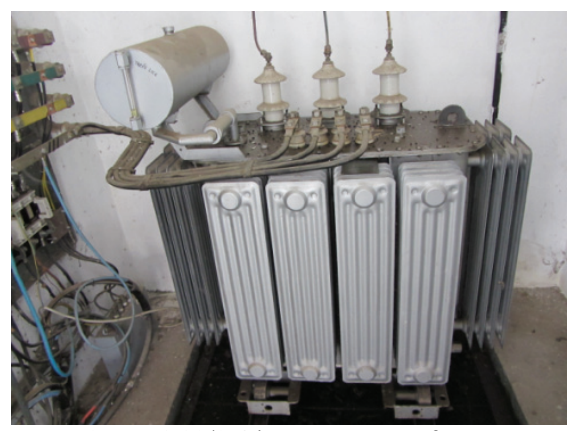

Figure 1 10/0,4 kV power transformer

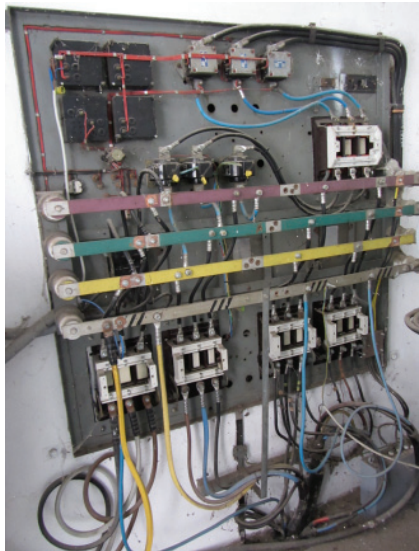

Figure 2 The main board with distribution lines of electrical subsystems 
The practical application of infrared thermography in the energy inspection of electrical installations will be presented for the part of the electric power system shown in Figs. 1 and 2.

\section{Technical standards, education and knowledge required for a correct interpretation of thermograms}

Education in the field of non-destructive testing is defined by the standard ISO 9712:2012 Non-destructive testing - Qualification and certification of NDT personnel. ISO 9712:2012 defines three levels of education in the field of NDT, [1].The content of the necessary knowledge in the field of thermal imaging is described best in BS ISO 18436-7:2014 "Condition monitoring and diagnostics of machines - Requirements for qualification and assessment of personnel Part 7: Thermography", [2]. Tab. 1 describes the requirements of ISO $18436-7$ in terms of knowledge necessary for certain levels of education.

Table 1 Requirements of thermographic auditors for each level of specialisation as described in ISO 18436-7 [3]

\begin{tabular}{|c|l|}
\hline $\begin{array}{c}\text { Level of } \\
\text { specialisation }\end{array}$ & \multicolumn{1}{|c|}{ Requirements } \\
\hline First level & $\begin{array}{l}\text { The professional operator is able to conduct a } \\
\text { Thermographic Audit using well-defined } \\
\text { procedures, to evaluate the analysis results and } \\
\text { to process elementary post-elaboration activity } \\
\text { of thermal images. He needs } 32 \mathrm{~h} \text { of training } \\
\text { and } 12 \text { certified months (or 400 h) of } \\
\text { professional activity. }\end{array}$ \\
\hline Second level \\
$\begin{array}{l}\text { The professional operator is able to conduct an } \\
\text { advanced Thermographic Audit through the } \\
\text { usage of many operating instruments, and to } \\
\text { identify the right corrective action for the } \\
\text { observed problem. He needs } 64 \mathrm{~h} \text { of training } \\
\text { and 24 certified months (or 1,200 h) of } \\
\text { professional activity. }\end{array}$ \\
\hline Third level \\
$\begin{array}{l}\text { The professional operator is able to develop } \\
\text { procedures, software and advanced instructions } \\
\text { for the correct use of Thermography. He is also } \\
\text { capable to identify complicated conditions and } \\
\text { to recommend thermodynamics corrective } \\
\text { actions. He needs 96 h of training and 48 } \\
\text { certified months (or 1,920 h) of professional } \\
\text { activity. }\end{array}$ \\
\hline
\end{tabular}

Knowledge needed specifically for the building sector is described in ISO 6781-3:2009 "Performance of buildings - Detection of heat, air and moisture irregularities in buildings by infrared methods - Part 3 Qualifications of equipment operators, data analysts and report writers", [4]. Before ISO 6781-3:2009, guidelines for the building sector were presented in EN 13187:1998 "Thermal performance of buildings - Qualitative detection of thermal irregularities in building envelopes -- Infrared method" (ISO 6781:1983 modified). The application in the field of mechanical engineering is described best in ISO 18434-1:2008 "Condition monitoring and diagnostics of machines - Thermography - Part 1: General procedures" [5]. In addition to formal education, practical experience and deep understanding of the behaviour of the analysed objects as well as the influence of emissivity are necessary for the interpretation of thermograms. A mistake that cannot be corrected after capturing a thermal image is well known under the acronyms FORD and RAT. FORD is an acronym which refers to focus, range and distance, and the acronym RAT refers to reflected apparent temperature.

\section{Applications of thermal imaging in the field of power engineering}

Problems detected by an infrared camera can be seen only while the equipment is in the operating state. The use of thermal imaging in the electric power industry is closely related to the measurement of electrical quantities, primarily the amount of current, which implies dissipation in individual elements of the system. The task to measure electrical quantities and to open the cabinets should be entrusted to an authorised electrician so that the person performing thermal imaging can undisturbedly audit the system. Thermograms of the power subsystem shown in Figs. 1 and 2 can be seen in Figs. 3 and 4.

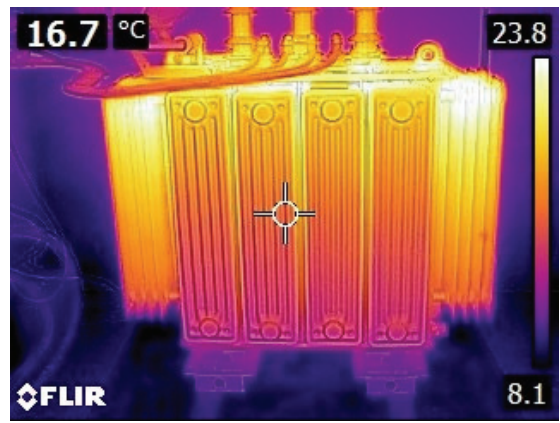

Figure 3 Electric power supply transformer

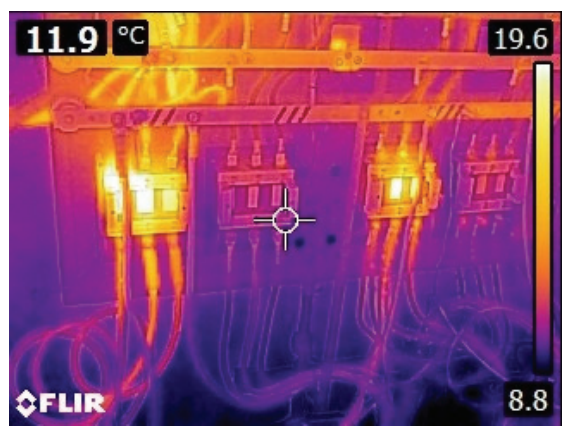

Figure 4 Basic electricity distribution lines

Thermograms themselves without measuring electrical quantities can lead to misconceptions about the safety of the installation.

The application of thermal imaging analysis was performed on the distribution power feeder of the $10 / 0,4 \mathrm{kV}$ TS shown in Fig. 2. There area lot of challenges that may arise during the inspection. A seemingly hotspot problem can be seen during IR inspection but in fact it can be the reflection of body heat, emissivity variation, solar gain or in some cases eddy current heat manifestations. Weather can influence the IR survey, too; hence wind, rain, fog, snow can change IR readings. The first and foremost challenge is the emissivity setting. Emissivity as a ratio of thermal radiation from the surface to radiation from the black body at the same temperature was set at the time of audit to 0,8 in order to take into account the large diversity of emissivity for a large number of different materials and in accordance with empirical recommendations [6]. 
Determination of emissivity is a significant challenge. The basic rule to be taken into account is the following: everything that seems to be a problem at emissivity set to 1 will be a problem even at lower emissivity values.

The recommended emissivity setting for electrical installation inspection is 0,9 according to information obtained from the Infrared Training Centre (ICT). The reason for this is that the emissivity range for most of the paints and insulating materials ranges between 0,9 and 0,95. In Fig. 5, one can see a great difference in emissivity among conductors and insulators as well as the directional dependence of emissivity on the angle $\Theta$ of the camera and the surface of the object under observation.

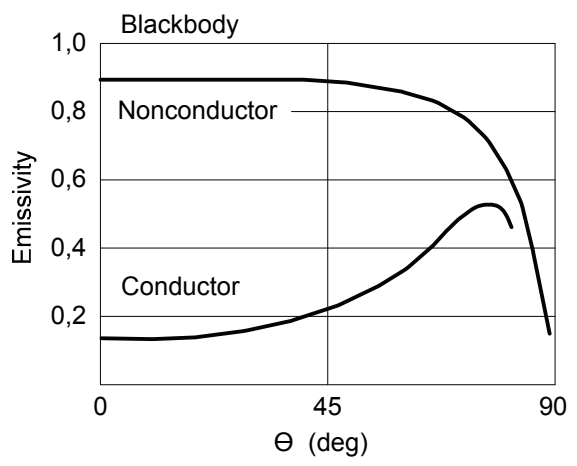

Figure 5 Directional dependence of emissivities [8]

Awide range of different emissivity values is obvious for conductors in the case of small changes in the camera angle. Emissivity of conductors primarily depends on the degree of oxidation. As the most common metal in electricity distribution, copper has different emissivity values. Emissivity as a function of temperature for different degrees of oxidation can be seen in Fig. 6.

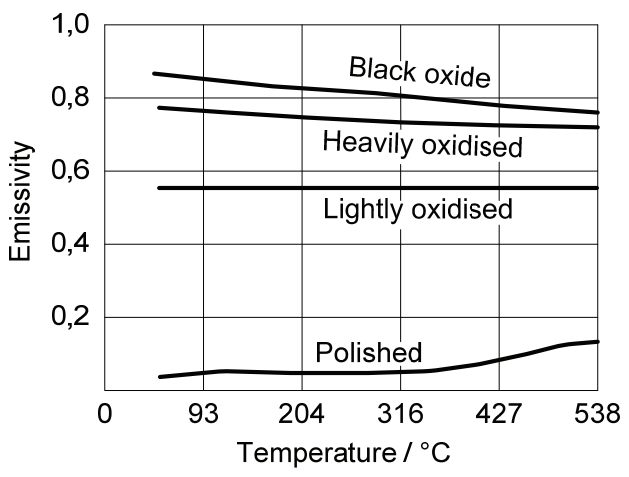

Figure 6 The effect of oxidation on emissivity of copper [8]

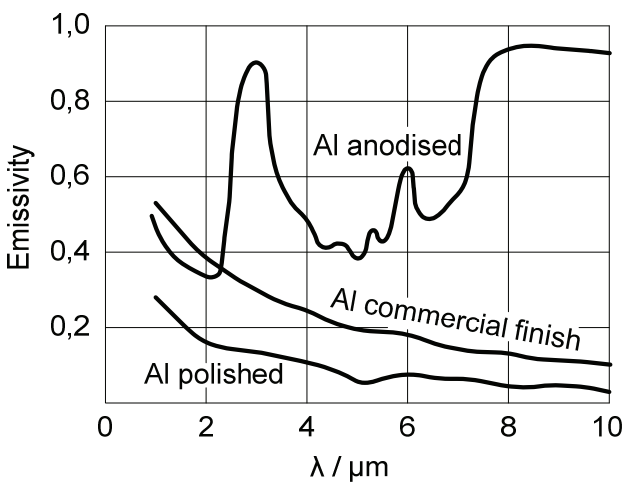

Figure 7 Wavelength dependence of emissivity of aluminium [8]
In addition to the dependency of emissivity on the angle of recording, object temperature and the degree of oxidation, the range of wavelengths used for thermal analysis is also important. Fig. 7 shows the wavelength dependence of emissivity on the character of the surface finishing of aluminium, which is the second most frequently used material in distribution of electrical energy.

From Figs. 5, 6 and 7 it is clear that the choice of emissivity is not an easy task to do and it is possible to make a mistake even in the case of an extremely experienced user. In the analysed example, due to selection of an inappropriate value of emissivity, the result would be a significant deviation of the measured temperature value. The difference between the selected emissivity 0,8 and the recommended emissivity 0,9 by the measurements carried out means a round $3{ }^{\circ} \mathrm{C}$ higher temperature reading. In the case of emissivity 0,7 , the temperature will increase by $6,8{ }^{\circ} \mathrm{C}$. Thermograms are interpreted on the basis of changes in the value of the apparent temperature, using the analysis of surfaces with greater emissivity, and avoiding the shiny metal parts. The analysis focuses on the ceramic casing of high capacity fuses, as can be seen in Figs. 8 and 9.

\section{Assessment of power installations safety based on a thermogram}

In the field of electrical engineering, there is no consensual standard of safety assessments based on the infrared survey. In the IR practice, the delta-T criterion is used to assess the state of electrical equipment. A wide variety of different delta-T criteria is in use. Experiencebased maintenance actions related to the temperature difference are shown in Tab. 2, [9].

Table 2 Experience-based classification system for electrical and/or mechanical equipment

\begin{tabular}{|c|c|l|}
\hline Priority & Delta-T $/{ }^{\circ} \mathrm{C}$ & \multicolumn{1}{|c|}{ Recommended action } \\
\hline 1 & $>40$ & $\begin{array}{l}\text { Corrective measures required } \\
\text { immediately }\end{array}$ \\
\hline 2 & $20 \div 40$ & $\begin{array}{l}\text { Corrective measures required } \\
\text { as soon as possible (ASAP) }\end{array}$ \\
\hline 3 & $10 \div 20$ & $\begin{array}{l}\text { Corrective measures required as } \\
\text { schedulling permits }\end{array}$ \\
\hline 4 & $1 \div 10$ & $\begin{array}{l}\text { Corrective measures should be taken } \\
\text { in the next maintenance period }\end{array}$ \\
\hline
\end{tabular}

Table 3 Experience-based classification system for electrical lowvoltage distribution and control equipment

\begin{tabular}{|c|c|l|}
\hline Priority & Delta-T $/{ }^{\circ} \mathrm{C}$ & \multicolumn{1}{|c|}{ Recommended action } \\
\hline 1 & $>30$ & $\begin{array}{l}\text { Corrective measures required } \\
\text { immediately }\end{array}$ \\
\hline 2 & $20 \div 30$ & $\begin{array}{l}\text { Corrective measures required } \\
\text { ASAP }\end{array}$ \\
\hline 3 & $10 \div 20$ & $\begin{array}{l}\text { Corrective measures required on a } \\
\text { priority schedulling basis }\end{array}$ \\
\hline 4 & $0 \div 10$ & $\begin{array}{l}\text { Corrective measures required in the } \\
\text { next schedulling maintenance period } \\
\text { or as schedulling permits }\end{array}$ \\
\hline
\end{tabular}

In [10], the commonly used delta-T criterion presented in Tab. 2 is classified as a criterion for high voltage distribution equipment and it divides commonly used charts into two voltage levels, i.e., high and low 
voltage. The delta- $T$ temperature criterion based on temperature rise of a component relative to the ambient temperature for low-voltage distribution and control equipment according to [10] is shown in Tab. 3 .

The major problem of the delta- $T$ criterion is that it does not take into account component load. That is why there are currently more than 30 organisations that have developed their own maintenance methodology. The most famous is the NETA Inter National Electrical Testing Association. NETA MTS-2005 (Maintenance Testing Specification), given in Tab. 4, suggests actions based on the temperature difference between similar components and based on the comparison between component and ambient air temperature, adopted from $[10,11]$.

Table 4 NETA thermographic survey suggested actions based on the temperature rise

\begin{tabular}{|c|c|c|c|}
\hline \multirow{2}{*}{ 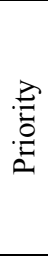 } & \multicolumn{2}{|c|}{$\begin{array}{l}\text { The temperature difference } \\
\text { (Delta-T) based on } \\
\text { comparisons between }\end{array}$} & \multirow[b]{2}{*}{ Recommended action } \\
\hline & $\begin{array}{l}\text { Similar } \\
\text { components } \\
\text { under similar } \\
\text { loading }\end{array}$ & $\begin{array}{l}\text { Components } \\
\text { and ambient air } \\
\text { temperatures }\end{array}$ & \\
\hline 1 & $>15^{\circ} \mathrm{C}$ & $>40^{\circ} \mathrm{C}$ & $\begin{array}{l}\text { Major discrepancy; } \\
\text { repair immediately }\end{array}$ \\
\hline 2 & - & $21 \div 40^{\circ} \mathrm{C}$ & $\begin{array}{l}\text { Monitor conntinuously } \\
\text { until corrective } \\
\text { measures can be } \\
\text { accomplished }\end{array}$ \\
\hline 3 & $4 \div 15^{\circ} \mathrm{C}$ & $11 \div 20^{\circ} \mathrm{C}$ & $\begin{array}{l}\text { Indicate probable } \\
\text { deficiency; repair as } \\
\text { time permits }\end{array}$ \\
\hline 4 & $1 \div 3{ }^{\circ} \mathrm{C}$ & $1 \div 10^{\circ} \mathrm{C}$ & $\begin{array}{l}\text { Possible deficiency; } \\
\text { warrants investigation }\end{array}$ \\
\hline
\end{tabular}

Experience gained in the military sector is summarised in Tab. $5[9,13]$.

Table 5 Electric inspection criteria for direct measurements (ICT Thermography Basic 2014) [12]

\begin{tabular}{|c|c|c|l|}
\hline $\begin{array}{c}\text { Temperature } \\
\text { rise between } \\
\text { component } \\
\text { and ambient } \\
\text { temperature } \\
/{ }^{\circ} \mathrm{C}\end{array}$ & $\begin{array}{c}\text { Repair } \\
\text { priority }\end{array}$ & \multicolumn{1}{|c|}{ Remarks } \\
\hline 1 & $>70$ & Immediate & $\begin{array}{l}\text { Component failure is } \\
\text { imminent, complete repairs } \\
\text { immediatly }\end{array}$ \\
\hline 2 & $40 \div 69$ & Mandatory & $\begin{array}{l}\text { Component failure almost } \\
\text { certain unless corrective } \\
\text { action is taken }\end{array}$ \\
\hline 3 & $25 \div 39$ & Important & $\begin{array}{l}\text { Component failure probable } \\
\text { unless corrective action is } \\
\text { taken }\end{array}$ \\
\hline 4 & $10 \div 24$ & As desired & $\begin{array}{l}\text { Component failure } \\
\text { improbable; corrective action } \\
\text { required in the next } \\
\text { maintenance period or as } \\
\text { schedulling permits }\end{array}$ \\
\hline
\end{tabular}

In Croatia, the Croatian National Electricity Company HEP is the most experienced in the field of thermographic analysis of electrical power distribution systems. Experience-based priorities of decision making by HEP in the field of maintenance of transformers and related equipment in the distribution networks are shown in Tab. $6[6]$.

Table 6 Decision making priorities on infrared thermography in transformer and equipment maintenance in accordance with the empirical methods, in conformity with [6]

\begin{tabular}{|c|c|c|c|}
\hline Priority & $\begin{array}{c}\mathrm{TS} 35 / 10 \\
\mathrm{kV}\end{array}$ & $\begin{array}{c}\text { TS10/0.4 } \\
\mathrm{kV}\end{array}$ & $\begin{array}{c}\text { General example of } \\
\text { fault priorities }\end{array}$ \\
\hline A & $\begin{array}{c}T>50^{\circ} \mathrm{C} ; \\
\Delta T>30^{\circ} \mathrm{C}\end{array}$ & $\begin{array}{c}T>60{ }^{\circ} \mathrm{C} \\
\Delta T>40{ }^{\circ} \mathrm{C}\end{array}$ & $\begin{array}{l}\text { Very serious fault that } \\
\text { requires immediate } \\
\text { attention. Absolute } \\
\text { temperature }>80^{\circ} \mathrm{C} \text { or } \\
\Delta T>30^{\circ} \mathrm{C}\end{array}$ \\
\hline B & $\begin{array}{c}\Delta T= \\
15 \div 30^{\circ} \mathrm{C}\end{array}$ & $\begin{array}{c}\Delta T= \\
15 \div 25^{\circ} \mathrm{C}\end{array}$ & $\begin{array}{c}\text { Serious defect that } \\
\text { requires attention in the } \\
\text { shortest time possible, } \\
\Delta T=5 \div 30^{\circ} \mathrm{C}\end{array}$ \\
\hline $\mathrm{C}$ & $\Delta T<15^{\circ} \mathrm{C}$ & $\Delta T<15^{\circ} \mathrm{C}$ & $\begin{array}{c}\text { Disturbance which } \\
\text { requires observation in } \\
\text { the following period, } \Delta T \\
\text { up to } 5^{\circ} \mathrm{C}\end{array}$ \\
\hline
\end{tabular}

Infrared inspection is useful when the equipment is under rated load because some hotspots are hardly noticeable if the current is low. Criteria of the temperature difference refer to the temperature rise of components that are under nominal load. In real terms, apparent temperature (the temperature registered by the camera) of each component of the system is affected by rated current, actual current measured in real time, ambient temperature and by the criterion of temperature differences (delta-T). Fig. 8 shows all the elements that affect the temperature rise of the components in the electrical power distribution system. It is assumed that there is no too much harmonic distortion in the distribution network as can be seen in [7].

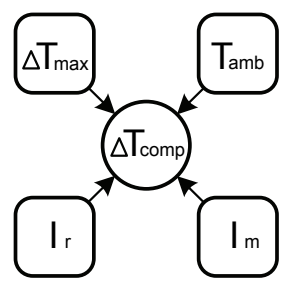

Figure 8 Variables that influence delta-T criteria

In the case of real load of each component with the operating current value less than the rated current, it is necessary to calculate the allowed difference of the temperature increase according to the following expressions:

$T_{\text {comp }}=\Delta T_{\max } \cdot\left(\frac{I_{m}}{I_{r}}\right)^{n}+T_{\mathrm{amb}}$

$\Delta T_{\text {corr }}=T_{\text {comp }}-T_{\text {amb }}$

$\Delta T_{\text {corr }}=\Delta T_{\max } \cdot\left(\frac{I_{m}}{I_{r}}\right)^{n}$

where $T_{\text {comp }}$ - maximum allowable temperature of components; $T_{\mathrm{amb}}{ }^{-}$ambient temperature; $\Delta T_{\text {corr }}{ }^{-}$ allowed temperature rise of components under measured load $\Delta T_{\max }$ - allowed temperature rise of components under rated load; $I_{r}$ - rated load (amperes); $I_{m}$ - measured load (amperes); and $n$ exponent 1,6 $\div 2,0$.

Under ideal conditions, the exponent of the ratio $I_{m} / I_{r}$ has the value 2,0 ; but in real terms, according to[6], 
the exponent ranges between 1,68 and 1,7. For example, in the case of applying the criteria in Tab. 2, after an increase in the temperature by $12,48{ }^{\circ} \mathrm{C}$ above the temperature of other components, the power system element which runs on $50 \%$ of rated load becomes immediately subject to maintenance.

\section{Thermal analysis of 12 conductors of the primary distribution subsystem}

By the analysis of thermographs the temperature difference between similar components is essential. It is thereby necessary to take account of the fact that some elements have different maximum values of the allowed temperature. As an example, the upper temperature limit for $\mathrm{PVC}$ is $70{ }^{\circ} \mathrm{C}$, and for ethylene-propylene and reticulated polyethylene cabels it is $90{ }^{\circ} \mathrm{C}$. In Fig. 9, one can see the first six conductors of the electric power distribution subsystem, i.e., two three-phase lines. At the first LV (low voltage) fuse block, i.e., in measurement area Ar1, the highest recorded temperature, the minimum recorded temperature and the average temperature were $42,8{ }^{\circ} \mathrm{C}, 11,1^{\circ} \mathrm{C}$, and $19,8{ }^{\circ} \mathrm{C}$, respectively. Temperature analysis over the lines located on the other LV fuse block indicates the maximum recorded temperature of $11,8{ }^{\circ} \mathrm{C}$, the minimum recorded temperature of $10,3{ }^{\circ} \mathrm{C}$ and the average temperature of $11,1^{\circ} \mathrm{C}$.

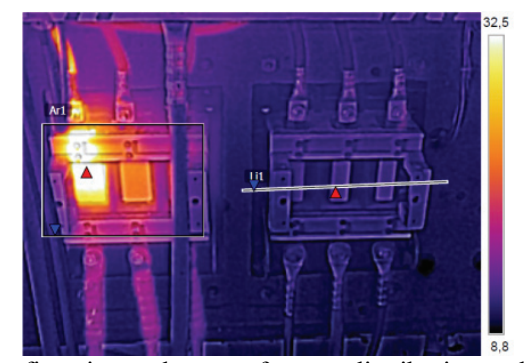

Figure 9 The first six conductors of power distribution and temperature measuring areas Ar1 and Li1

The measured values of electrical quantities for individual conductors (Fig. 9 from left to right) as well as the temperature values are shown in Tab. 7.

Table 7 The measured values of electrical and thermal quantities for

\begin{tabular}{|l|c|c|c|c|c|c|}
\hline \multicolumn{1}{|c|}{ Line } & 1 & 2 & 3 & 4 & 5 & 6 \\
\hline Voltage (V) & 239 & 239 & 240 & 239 & 239 & 239 \\
\hline Current (A) & 45,4 & 61,2 & 75,8 & 15,5 & 18,2 & 20,5 \\
\hline Power (kW) & 8,05 & 11,3 & 15,1 & 1,89 & 3,17 & 3,48 \\
\hline P. F. & 0,74 & 0,77 & 0,84 & 0,51 & 0,73 & 0,71 \\
\hline Temperature & 42,8 & 24,2 & 21,2 & 11,9 & 11,9 & 11,9 \\
\hline Priority & 2 & 3 & 3 & 4 & 4 & 4 \\
\hline
\end{tabular}

Data from Tab. 7 show that the value of the measured temperature of the first conductor is not in accordance with the electrical load on this conductor. Construction of the first LV fuse blockpoints to the need for further analysis of the contacts of conductors 2 and 3. Accepting the delta-T criteria based on Tabs. 2 and 4, i.e., the temperature difference of $31,7{ }^{\circ} \mathrm{C}(42,8 \div 11,1)$, corrective maintenance action for conductor 1 is recommended to be undertaken as soon as possible. Unlike the second conductor, where the priority of maintenance is unquestionable, the third conductor is characterized by priority 3, although it has $24 \%$ greater load and $23 \%$ lower registered apparent temperature.

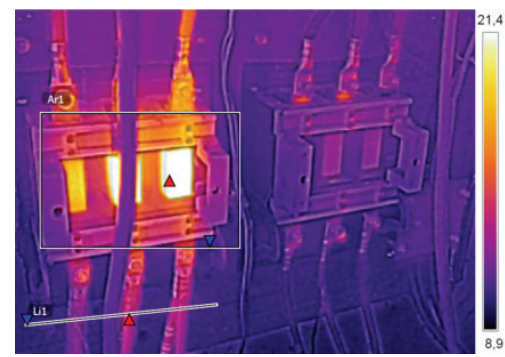

Figure 10 The next six conductors of power distribution and temperature measuring areas Ar1 and Li1

Fig. 10 presents the other six conductors of power distribution, i.e., two LV fuse blocks with three-phase lines each. On the third LVfuse block (Fig. 2 counting from left to right), thus in measurement area Ar1, the highest recorded temperature was $25,7^{\circ} \mathrm{C}$, the minimum recorded temperature was $10,1{ }^{\circ} \mathrm{C}$ and the average temperature was $14,7{ }^{\circ} \mathrm{C}$. Temperature analysis over the line located on the other LVfuse block indicates the maximum recorded temperature of $13,6{ }^{\circ} \mathrm{C}$, the minimum recorded temperature of $10,1{ }^{\circ} \mathrm{C}$ and the average temperature of $11,2^{\circ} \mathrm{C}$.

Table 8 The measured values of electrical and thermal quantities on

\begin{tabular}{|l|c|c|c|c|c|c|}
\hline \multicolumn{1}{|c|}{ Line } & 7 & 8 & 9 & 10 & 11 & 12 \\
\hline Voltage (V) & 239 & 239 & 239 & 239 & 239 & 238 \\
\hline Current (A) & 34,5 & 58,4 & 56,1 & 43,1 & 54,7 & 36,1 \\
\hline Power (kW) & 5,25 & 8,92 & 6,61 & 10,2 & 13 & 8,49 \\
\hline P. F. & 0,63 & 0,64 & 0,49 & 0,99 & 1 & 0,99 \\
\hline Temperature & 19,4 & 25,1 & 25,7 & 12,8 & 12,8 & 12,3 \\
\hline Priority & 4 & 3 & 3 & 4 & 4 & 4 \\
\hline
\end{tabular}

Data from Tab. 8 indicate that with their temperature difference of $14{ }^{\circ} \mathrm{C}$ i.e. $14,6{ }^{\circ} \mathrm{C}$ above the average temperature of surrounding components, conductors 8 and 9 can be classified into the third category of maintenance priority. The values of temperature on all conductors are not even close to the maximum allowed values which the relevant materials of electrical distribution can be exposed to. A graphic display of measured values of the temperature and the associated fault ratings according to the delta T criterion from Tabs. 2 and 3 are presented in Fig. 11.

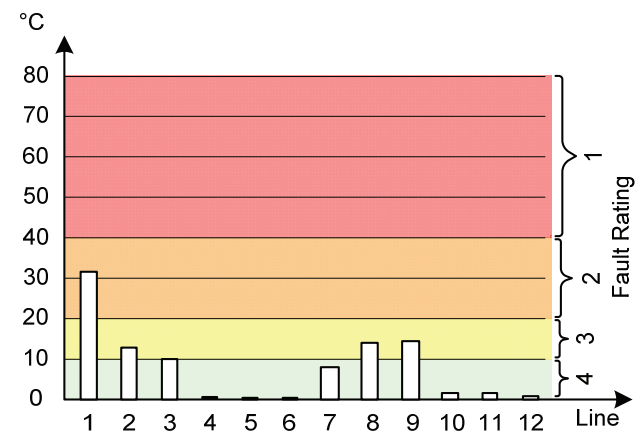

Figure 11 The delta-T criterion and the proposed maintenance priorities without the load value taken into account

After expressing delta-T in Tabs. 7 and 8 and performing correction according to Eq. (3), the equivalent 
value of the temperature difference $\left(\Delta T_{\text {corr }}\right)$ is obtained. The basic problem is that nominal values of all fuses are unknown and they cannot be estimated on the basis of the physical size of the fuse. Assuming that individual registers are fitted with fuses of the same characteristics and that the maximum measured current corresponds to the rated current for all fuses in the register, it is possible to calculate the correction to the delta-T criterion $\left(T_{\text {corr }}\right)$.

Table 9 A corrected delta $\mathrm{T}$ criterion and the proposed maintenance

\begin{tabular}{|l|c|c|c|c|c|c|}
\multicolumn{7}{c|}{ priority for conductors $1 \div 6$} \\
\hline Line & 1 & 2 & 3 & 4 & 5 & 6 \\
\hline Temperature & 42,8 & 24,2 & 21,2 & 11,9 & 11,9 & 11,9 \\
\hline Delta-T & 31,7 & 13,1 & 10,1 & 0,8 & 0,8 & 0,8 \\
\hline Delta-T corr. & 79,76 & 19,25 & 10,10 & 1,32 & 0,99 & 0,80 \\
\hline Priority & 1 & 3 & 3 & 4 & 4 & 4 \\
\hline
\end{tabular}

From Tab. 9 it can be seen that the first conductor on the base of the absolute temperature criterion and the delta-T criterion is under priority 1, i.e., immediate maintenance is required. The second conductor is almost under priority 2 , but because of Tab. 3 , it must be classified under priority 3 as well as the third conductor, i.e., important maintenance. Since all three conductors are in the same registry, maintenance of all of them should be undertaken immediately.

Table 10 A corrected delta-T criterion and the proposed maintenance priority for conductors $7 \div 12$

\begin{tabular}{|l|c|c|c|c|c|c|}
\hline \multicolumn{1}{|c|}{ Line } & 7 & 8 & 9 & 10 & 11 & 12 \\
\hline Temperature & 19,4 & 25,1 & 25,7 & 12,8 & 12,8 & 12,3 \\
\hline Delta-T & 8,3 & 14 & 14,6 & 1,7 & 1,7 & 1,2 \\
\hline Delta-T corr. & 21,41 & 14,00 & 15,70 & 2,61 & 1,70 & 2,54 \\
\hline Priority & 2 & 3 & 3 & 4 & 4 & 4 \\
\hline
\end{tabular}

In Tab. 10 it is obvious that the assessment of the maintenance priority for conductor 7 according to Table 8 was wrong because the loading was not taken into account. After correcting the delta-T criterion, the classification of conductor 7 changes from priority 4 to priority 2, corrective measures are required ASAP, according to Tab. 2. Conductors 10, 11 and 12 do not require corrective maintenance work. A graphic display of measured values of the temperature and the associated fault ratings according to the delta $\mathrm{T}$ corr. Criterion from Tabs. 2 and 3 is presented in Fig. 12.

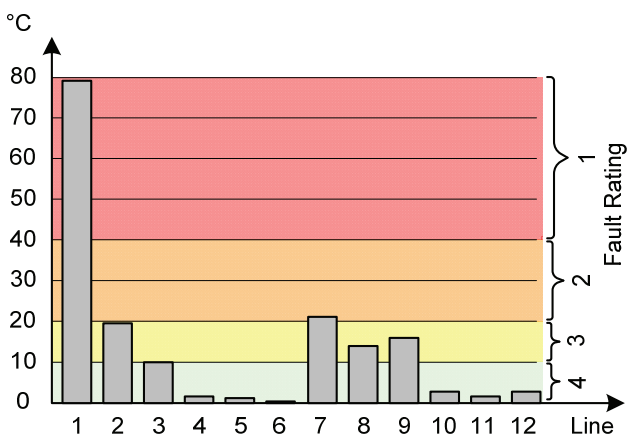

Figure 12 The delta-T criterion and the proposed maintenance priorities with correction of temperature based on the measured and nominal load value

Figs. 11 and 12 show that the initial assessment of the maintenance priority without taking into account the real load can lead to wrong estimates of the actual maintenance priorities.

\section{Conclusion}

As a non-destructive method of testing electrical installations, infrared thermography is a simple way to quickly spoting the potential problems. Training and experience of the operator are crucial for a correct interpretation of thermograms. The complexity of the field is evident in the fact that there is no single technical standard in thermal imaging. Thermovision inspection of the electric power distribution system has to start by the emissivity setting of 0,9 because the amount of surfaces with different emissivity is extremely large. A wrong choice of emissivity results very easily in a wrong value of apparent temperature readings. There are two basic criteria for spotting possible problems, i.e., the criterion of absolute temperature and the criterion of the temperature difference. The criterion of absolute temperature comes down to determination and comparison of temperature values for each component from the thermogram according to the values materials can withstand without damage. The delta-T criterion takes into account the temperature difference between similar components under similar load conditions, and based on the temperature difference, the operator can make decisions on the operating state of each component. In the case of a major difference between the measured load and the rated value, a correction of the allowed temperature rise should be calculated. Thereafter, with the corrected temperature value, a decision on maintenance should be performed according to the presented criteria. Thermography is a very practical method for the energy audit and maintenance of electrical installations, but it is very complex for evaluation and making judgments. The thermal imaging camera operator has to continuously broaden his or her knowledge in a relatively wide area of technical expertise.

\section{References}

[1] ISO 9712:2012 Non-destructive testing - Qualification and certification of NDT personnel

[2] BS ISO 18436-7:2014 Condition monitoring and diagnostics of machines - Requirements for qualification and assessment of personnel Part 7: Thermography

[3] Dall'O', G. Green Energy Audit of Buildings, Green Energy and Technology, Springer-Verlag London, 2013.

[4] ISO 6781-3:2009 Performance of buildings - Detection of heat, air and moisture irregularities in buildings by infrared methods - Part 3 - Qualifications of equipment operators, data analysts and report writers

[5] ISO 18434-1:2008 Condition monitoring and diagnostics of machines - Thermography - Part 1: General procedures

[6] Muštran, D. Thermovision camera, Part 3, Seminar paper, Osijek, 2004.

[7] Stojkov, M.; Trupinić, K.; Nikolovski, S. Procedure for determination of harmonic distortion along the distribution network. // Tehnicki vjesnik-Technical Gazette. 4, 16(2009), pp. 19-26.

[8] Mensah, F. K. Condition Assessment of Electrical Contacts of Disconnectors, Master of Science Thesis, Supervisor: Dr. ir. S. Meijer, Delft University of Technology, 2011. 
[9] Infraspection Institute, "Standard for Infrared Inspection of Electrical Systems \& Rotating Equipment", 2008.

[10] Gill, P. Electrical Power Equipment Maintenance and Testing. CRC Press, 1998.

[11] Lyon Jr., B. R.; Orlove, G. L.; Peters, D. L. The relationship between current load and temperature for quasi-steady state and transient conditions, In Thermosense XXII, Proceedings of SPIE Vol. 4020, 2000.

[12] ICT Infrared Training Center, Course manual Thermography Basic course, 2009.

[13] International Electrical Testing Association, http://www.netaworld.org (30.04.2015).

\section{Authors' addresses}

Hrvoje Glavaš, PhD, Assistant Professor

Josip Juraj Strossmayer University of Osijek,

Faculty of Electrical Engineering, Computer Science and

Information Technology Osijek,

Kneza Trpimira $2 b$

31000 Osijek, Croatia

E-mail: hrvoje.glavas@etfos.hr

\section{Lajos Józsa, PhD, Full professor}

Josip Juraj Strossmayer University of Osijek,

Faculty of Electrical Engineering, Computer Science and

Information Technology Osijek,

Kneza Trpimira $2 b$

31000 Osijek, Croatia

E-mail: lajos.jozsa@etfos.hr

Tomislav Barić, PhD, Associate Professor

Josip Juraj Strossmayer University of Osijek,

Faculty of Electrical Engineering, Computer Science and Information Technology Osijek,

Kneza Trpimira 2b

31000 Osijek, Croatia

E-mail: tomislav.baric@etfos.hr 